\title{
Level of Knowledge of Agricultural Science Graduate Students about Climate Change Mitigation and Adaptation Practices of Agriculture
}

\author{
Nabeel M. Gazzaz ${ }^{1, *}$ \& Motasem M. Al-Masad ${ }^{2}$ \\ ${ }^{1}$ Department of Climate Change and Sustainable Agriculture, Faculty of Agriculture and Science, Jarash University, \\ Jarash, 26150, Jordan \\ ${ }^{2}$ Department of Animal Production and Protection, Faculty of Agriculture and Science, Jarash University, Jarash, \\ 26150, Jordan \\ *Correspondence: Department of Climate Change and Sustainable Agriculture, Faculty of Agriculture and Science, \\ Jarash University, Jarash, 26150, Jordan. Tel: 962-78-079-0891. E-mail: NabeelMGazzaz@yahoo.com
}

Received: August 27, 2021

Accepted: November 29, $2021 \quad$ Online Published: December 12, 2021

doi:10.5430/wje.v11n6p50

URL: https://doi.org/10.5430/wje.v11n6p50

\begin{abstract}
Climate change (CC) is a global environmental problem and source of concern. Effective planning and implementation of CC mitigation and adaptation may arise from knowledge of its causes and effects. Therefore, dissemination of knowledge is highly important for ensuring that the knowledge grows and spreads amongst the various stakeholders and that it is turned into action. The students of today are the leaders and policy makers of tomorrow. They will effectively serve as change agents once their knowledge base has been well established. This study provides analysis of graduate students' level of knowledge of CC, its nature, causes, effects, mitigation, and adaptation. The study population was 57 agricultural science master's students in the Faculty of Agricultural Sciences in Jarash University, Jordan, and the sample consisted of 50 of those students. The study used online test as the knowledge assessment and data collection tool. Frequency distribution analysis uncovered that the sample students possess high level of general knowledge of CC, moderate level of knowledge of mitigation of CC, and high level of knowledge of adaptation to CC. As to the three investigated facets of general knowledge of CC, these students have high levels of knowledge of the nature and the effects of CC and moderate level of knowledge of its causes. These findings contribute to understanding of students' knowledge achievements and gaps and of the need for curricular reform in terms of structure and content that can be shared by agricultural science faculties around the World with similar CC graduate programs.
\end{abstract}

Keywords: climate change, knowledge, adaptation, mitigation, agricultural sciences, graduate students

\section{Introduction}

\subsection{Climate Change: Nature, Causes, and Effects}

Climate change (CC) has been defined in varying ways in the literature. The Intergovernmental Panel on Climate Change (IPCC) articulates that "Climate change refers to a change in the state of the climate that can be identified (e.g., by using statistical tests) by changes in the mean and/or the variability of its properties and that persists for an extended period, typically decades or longer. Climate change may be due to natural internal processes or external forcings such as modulations of the solar cycles, volcanic eruptions and persistent anthropogenic changes in the composition of the atmosphere or in land use" (IPCC, 2014, p. 120). Schwirplies (2018) defined CC as "a rise in the average global temperature over the past 150 years or in the future" (p. 309). More recently, Fawzy et al. (2020) defined it as shift in the climate patterns that is caused mainly by greenhouse gas (GHG) emissions from human activities and natural processes. In this respect, the GHGs have been defined by Easton and Faulkner (2014) as a "collection of human and naturally derived gases that trap heat within the atmosphere that can both regulate Earth's climate and contribute to climate change" (p. 6). The principal GHGs emitted by human activities are methane $\left(\mathrm{CH}_{4}\right)$, nitrous oxide $\left(\mathrm{N}_{2} \mathrm{O}\right)$, and carbon dioxide $\left(\mathrm{CO}_{2}\right)$. These gases trap the heat in the atmosphere and raise temperature of the Earth steadily above the natural levels (Easton \& Faulkner, 2014). However, Lineman et al. (2015) stressed the role of fossil fuels and $\mathrm{CO}_{2}$ in $\mathrm{CC}$ and defined it as "a change in global or regional climate 
patterns, in particular a change apparent from the mid to late $20^{\text {th }}$ century onwards and attributed to the increased levels of atmospheric carbon dioxide arising from the use of fossil fuels" (p. 3).

Climate change is caused by (i) natural processes, which include natural factors and forces like volcanic eruptions and solar radiation variations; and (ii) anthropogenic factors, namely, human activities (Kakaki, 2013; Odjugo, 2010). The human activities that cause CC correspond to either (i) emitting large volumes of GHGs into the atmosphere through, for example, fossil fuel burning, gas flaring, industrialization, and agricultural - and other waste burning; or (ii) reducing the amount of carbon that is removed from the atmosphere (Odjugo, 2010) by such activities as deforestation (Akrofi, Antwi, \& Gumbo, 2019; Falaye \& Okwilagwe, 2016). However, there is broad consensus among scientists currently on that the main cause of CC is human activities (Falaye \& Okwilagwe, 2016; Sulistyawati, Mulasari, \& Sukesi, 2018; Tobler, Visschers, \& Siegrist, 2012).

The main cause of CC is human activities that increase release of GHGs into the atmosphere or reduce their sinks in the environment. These gases are derived both from human activities and natural processes (Crowley, 2000; Frigg, Thompson, \& Wernd, 2015; Hulme et al., 2009; Olaniyi, Olutimehin, \& Funmilayo, 2019). In particular, the GHGs $\mathrm{CO}_{2}, \mathrm{CH}_{4}$, and $\mathrm{N}_{2} \mathrm{O}$ are the three largest individual contributors to $\mathrm{CC}$ (Lynch et al., 2021). A substantial cause of $\mathrm{CC}$ is fossil fuel burning, which releases $\mathrm{CO}_{2}$ and other GHGs into the atmosphere (Baer et al., 2019; Plotnikoff, Wright, \& Karunamuni, 2004). Agriculture too is a major contributor to anthropogenic CC (Jørgensen \& Termansen, 2016). In effect, agriculture and food production contribute the foregoing three GHGs (Lynch et al., 2021) and others such as ammonia $\left(\mathrm{NH}_{3}\right.$ ). Olaniyi et al. (2019) and Parant et al. (2016) support that the main cause of global warming and $\mathrm{CC}$ is the ongoing increase in the concentration of $\mathrm{CO}_{2}$ in the atmosphere due to emissions from deforestation, cement production, and fossil fuel burning, which constitute the major sources of $\mathrm{CO}_{2}$. Deforestation reduces $\mathrm{CO}_{2}$ sequestration whereas fossil fuel burning produces the largest volumes of the atmospheric $\mathrm{CO}_{2}$ and cement production ranks as the third largest $\mathrm{CO}_{2}$ producer (Olaniyi et al., 2019).

Climate change has widely-varying negative impacts on the ecosystem that include increased incidence and intensity of extreme weather conditions such as frost (Niles, Brown, \& Dynes, 2016), drought, thunderstorms, windstorms, rainstorms, floods, and tsunamis (Limantol et al., 2016; Olaniyi et al., 2019; Rahman et al., 2021). The negative impacts also include heat waves (Falaye \& Okwilagwe, 2016; Kakaki, 2013; Olaniyi et al., 2019; Onoja et al., 2011); wildfires (Falaye \& Okwilagwe, 2016); melting of ice caps (Kakaki, 2013; Onoja et al., 2011); rising sea levels (Kakaki, 2013; La Torre et al., 2020; Marty \& Yokochi, 2006; Onoja et al., 2011); coastal flooding and erosion (Agboola \& Emmanuel, 2016; Olaniyi et al., 2019); and soil erosion (Onoja et al., 2011). Erosion, the heat waves, and drought contribute to desertification (Kakaki, 2013), which aggravates the negative impacts of CC. Additionally, the deleterious impacts of CC encircle changes in rainfall trends and patterns (Easton \& Faulkner, 2014; Limantol et al., 2016; Marty \& Yokochi, 2006) and adverse effects on human, animal, and plant health (La Torre et al., 2020; Marty \& Yokochi, 2006) due, mainly, to proliferation of water-borne, vector-borne, and infectious diseases (Baer et al., 2019; Sulistyawati et al., 2018). Furthermore, climate change causes shortages of water supplies for domestic and agricultural use (Akrofi et al., 2019; Dhanya \& Ramachandran, 2016; Easton \& Faulkner, 2014; La Torre et al., 2020).

As far as agriculture, in specific, is concerned, the problems associated with CC encompass insect and pest infestations (Asrat \& Simane, 2018; Dhanya \& Ramachandran, 2016); weed proliferation (Ramesh \& Negi, 2014); crop damage and failure (Dhanya \& Ramachandran, 2016; Easton \& Faulkner, 2014; Kakaki, 2013); biodiversity loss (Akrofi et al., 2019; Kakaki, 2013; La Torre et al., 2020); deterioration of arable lands (Odjugo, 2010) and reduction of their areas due to land degradation (Asrat \& Simane, 2018); and reduction in crop yields (Agboola \& Emmanuel, 2016; Akrofi et al., 2019; Apata, 2011; Easton \& Faulkner, 2014; Limantol et al., 2016; Olaniyi et al., 2019). Moreover, climate change has been reported to be altering the incidence, distribution, and intensity of plant and animal pests and diseases (Ramesh \& Negi, 2014), in addition to those of alien and invasive species (Barkmann, Siebert, \& Lange, 2017; Ramesh \& Negi, 2014). Furthermore, climate change effects extend over rangelands and include spread of non-native invasive weeds, emergence of new weeds, and decline in the desirable grasses (Yung et al., 2015). A direct consequence of the aforementioned detrimental effects of $\mathrm{CC}$ is that plant and animal farm production and productivity drop tangibly in parts of the World (Apata, 2011; Easton \& Faulkner, 2014; Mkonda, He, \& Festin, 2018; Olaniyi et al., 2014), with concomitant negative implications for food security.

Policymakers and scientists in general agree on that $\mathrm{CC}$ has far more adverse impacts on the production ecosystems than positive outcomes (Easton \& Faulkner, 2014). It should be highlighted, however, that the net impact of CC varies qualitatively and quantitatively by climatic region (Apata, 2011; Olaniyi et al., 2019), season (Apata, 2011; Easton \& Faulkner, 2014), and farming system (Niles et al., 2016). As a result of the aforementioned negative effects 
of $\mathrm{CC}$, it has socio-cultural, economic, and political impacts on communities. However, a discussion of these impacts is out of scope of this study.

\subsection{Response to Climate Change: Mitigation and Adaptation}

\subsubsection{Mitigation}

Climate change adaptation and mitigation are the primary responses of the human community to $\mathrm{CC}$ in order to reduce its incidence and minimize its negative impacts on humans and the ecosystems. Mitigation of CC has been defined by IPCC (2014) as "A human intervention to reduce the sources or enhance the sinks of greenhouse gases $(G H G s) "$ (p. 125). In the context of agriculture, these two facets of mitigation, that is, reducing the sources and enhancing the sinks, have been affirmed recently by Pareek (2017), who stated that mitigation of CC is realized through farm management actions that lower GHG emissions and improve carbon sequestration by soil. Very recently, Marangoni et al. (2021) defined mitigation strategies as rules that prescribe reductions in the global $\mathrm{CO}_{2}$ gas emissions from the industry and fossil fuel burning. According to Schwirplies (2018), climate change mitigation encircles all the measures that help in reducing the GHG emissions like generation of energy from renewable resources and improving the energy use efficiency. In harmony with this, we tend to re-organize the various mitigation strategies in this paper in two categories: (i) energy conservation, which includes energy use efficiency, and (ii) energy substitution, that is, replacing the energy generated from non-renewable resources with energy that is produced from renewable resources. We maintain that all CC mitigation efforts revolve around these two strategies.

Examples of mitigation practices that focus on reduction of GHG emission include the use of energy-efficient equipment (e.g., light-emitting diode (LED) lights), devices, and vehicles; and the use of alternative fuels, e.g., solar energy (Mukhopadhyay, 2020; Niles et al., 2016; Sanneh et al., 2013), biofuel or biodiesel (Haden et al., 2012; Niles et al., 2016; Smith \& Olesen, 2010), and wind energy (Haden et al., 2012; Mukhopadhyay, 2020). Emissions of $\mathrm{CO}_{2}$ can be lowered via efficient energy use and reduced biomass burning (Pareek, 2017). Since, according to Tobler et al. (2012), the diesel-engine vehicle releases more $\mathrm{CO}_{2}$ per kilometer and person than a similar petrol-engine vehicle, then replacement of diesel-engine agricultural machinery and equipment with comparable petrol-engine machinery and equipment is a $\mathrm{CC}$ mitigation practice because this reduces $\mathrm{GHG}$ emissions.

Examples of mitigation practices that focus on enhancement of GHG sinks include tree planting (Atube et al., 2021; Duguma, Minang, \& van Noordwijk, 2014); afforestation (Atube et al. 2021; Duguma et al., 2014; Liu, Liu, \& Gao, 2020); reforestation (Duguma et al., 2014; Liu et al., 2020), and agroforestry (Pareek, 2017). In effect, agroforestry improves carbon sequestration and lowers GHG emissions from the terrestrial ecosystems, thus mitigating CC (Shrestha et al., 2018). Climate change can also be mitigated by increasing the concentration of soil organic matter (Jørgensen \& Termansen, 2016; Pareek, 2017). Many practices contribute to this, including use of organic fertilizers such as green or dry manure and plant residues (Jørgensen \& Termansen, 2016; Pareek, 2017; Shrestha et al., 2018), mulch (Esham \& Garforth, 2013; Limantol et al., 2016), compost (Pareek, 2017; Shrestha et al., 2018), boiochar (Shrestha et al., 2018), sludge (Pareek, 2017), and cover crops (Jørgensen \& Termansen, 2016; Limantol et al., 2016). Interestingly, while these practices increase the carbon sinks in soil, they contribute to adaptation to CC by, for example, increasing the soil moisture content and reducing susceptibility of soil to erosion.

Moreover, the agricultural CC mitigation measures encircle use of fuel-efficient farm equipment and reducing use of electricity in the farm operations (Haden et al., 2012). Additionally, mitigation practices include reducing use of nitrogen fertilizers and improving their use efficiency (Haden et al., 2012; Niles et al., 2016; Pareek, 2017). Further, organic farming is advocated by a number of researchers as a CC mitigation activity (e.g., Goh, 2011; Niles, 2008) since this agricultural production method has the highest potential for combating CC by (i) lowering the GHG emissions (Goh, 2011; Niles, 2008) and (ii) sequestering high amounts of carbon (Niles, 2008). Lastly, while conservation tillage, i.e., no (or zero) tillage or low (i.e., reduced) tillage, has both CC mitigation and adaptation effects (Pareek, 2017), many researchers advocate that it is a mitigation practice (e.g., Easton \& Faulkner (2014), Haden et al. (2012), and Shrestha et al. (2018)).

\subsubsection{Adaptation}

Adaptation to CC has been defined by IPCC as "The process of adjustment to actual or expected climate and its effects" (IPCC, 2014, p. 118). However, Easton and Faulkner (2014) defined adaptation to CC as a response that aims at reducing vulnerability of the biological systems to the $\mathrm{CC}$ effects. Examples of agricultural adaptation measures include the use of drought-resistant (drought-tolerant) crop varieties and species (Atube et al., 2021; Easton \& Faulkner, 2014; Haden et al., 2012; Hussain et al., 2020); cultivation of salt-tolerant crops (Dhanya \& Ramachandran, 2016; Liu et al., 2020); use of improved seeds and crop varieties (Asrat \& Simane, 2018; Atube et 
al., 2021); and cultivation of plants that have low water requirement (Haden et al., 2012). Agricultural diversification practices are too categorized as adaptation practices (Asrat \& Simane, 2018; Pareek, 2017; Sanneh et al., 2013). They include crop rotation (Asrat \& Simane, 2018; Esham \& Garforth, 2013; Smith \& Olesen, 2010), intercropping (Asrat \& Simane, 2018), and integrated (plant and animal) farming. Genetic improvement of the crops in order to develop varieties with high tolerance to high temperatures, drought, and salinity and with enhanced responsiveness to the growing $\mathrm{CO}_{2}$ concentrations in the atmosphere is another noteworthy adaptation practice (Ramesh \& Negi, 2014). Search for substitute and/or additional (new) water sources is too categorized as an adaptation practice (Haden et al., 2012; Niles et al., 2016). This can be achieved by such operations as water harvesting (Esham \& Garforth, 2013; Sanneh et al., 2013) and exploration of new water wells (Niles et al., 2016). In other respects, adaptation practices extend to irrigation and include water-conserving irrigation methods such as micro-sprinkler irrigation and drip irrigation (Haden et al., 2012; Hussain et al., 2020; Liu et al., 2020). Additionally, climate forecasting and projection (Hussain et al., 2020) and provision of early warning systems are CC adaptation measures (Dhanya \& Ramachandran, 2016; Hussain et al., 2020). Lastly, expansion of the protected areas has been pinpointed by a number of researchers (e.g., Sanneh et al. (2013)) as an adaptation measure.

\subsection{Climate Change Education}

Global climate change is considered by $97.0 \%$ of CC scientists as a man-made problem. This problem requires action on two critical tracks: mitigation and adaptation. However, implementation of mitigation and adaptation actions calls for capable policymakers and informed public. In general, the educated people are more knowledgeable of the risks which the CC poses and are well equipped with appropriate knowledge and skills to take informed decisions about CC responses on the local, national, regional, and international scales (Molthan-Hill et al., 2019). Indeed, higher education has critical role to play in educating the students about CC and linking it with social dimensions, including access to food and drinkable water and a shift to increased use of sustainable energy (Rees, 2003). Role of university in climate change education (CCE), from the perspective of Molthan-Hill et al. (2019), is of paramount importance if the scientific, environmental, social, and political challenges which the World is facing are to be met. The future leaders should make informed decisions and the public needs to embed the CC mitigation and adaptation tools and practices into everyday activities.

Various definitions of CCE have so far been formulated. However, what they all share in common is a stress on knowledge and on behavioral and attitudinal change. In effect, climate change education concerns helping the learners to understand global warming and $\mathrm{CC}$ and their current and future impacts while encouraging the change in people's attitudes and behaviors that is needed to put the World on a more sustainable track in the future (Boakye, 2015). According to Anderson (2012), climate change education should be integral part of Education for Sustainable Development (ESD), which is a critical tool for sustainable development and integral constituent of quality education (Filho et al., 2021). Anderson (2012) defined ESD as approach to teaching and learning that is based on the principles and ideals that underlie sustainability and which are applicable to all sorts, levels, and settings of education. Consequently, it is an education approach that promotes multi-stakeholder social learning; emphasizes empowerment of the citizens and societies; involves fundamental social and economic issues (e.g., human rights, gender equality, sustainable livelihoods, poverty reduction, and environmental education) in integrated manner; and encourages and promotes changes in behavior in such a way as to ensure that human behavior will contribute to more sustainable future. It empowers the people to change their thinking and actions towards sustainable future (Filho et al., 2021). In this respect, Dalelo (2011) maintains that "The environmentally literate person is described as a person who possesses the values, attitudes and skills that enable knowledge to be converted into action" (p. 85). Consequently, climate change education for sustainable education should equip the learners with the values and skills that enable them to convert the CC knowledge they acquire and accumulate into action.

Anderson (2012) argues that CCE has been defined narrowly in particular contexts as concentrating on environmental education and climate literacy within science classes. However, climate change education for sustainable development (CCESD) must be multidisciplinary and comprehensive; it should not only include appropriate content knowledge on CC, disaster risk reduction, social and environmental concerns, and sustainable lifestyles and consumption, but should also concentrate on the institutional environment in which that content is delivered to assure that the education systems and institutions themselves are climate-proofed and resilient, in addition to being green and sustainable. Evidence uncovers that the educational interventions are successful the most when they concentrate on tangible, local, and actionable facets of environmental education, CC, and sustainable development, particularly the aspects that relate to individual behavior. Within this context, and in an investigation of the role of pre-tertiary science curricula in Ghana in CCE, Boakye (2015) recommended that the methods of CC teaching and learning should be improved for effective behavioral and attitudinal changes so that they can help in 
mitigation and adaptation efforts and activities.

Review of the literature revealed lack of any earlier investigations of graduate students' knowledge of CC and mitigation and adaptation practices, both the agricultural science and other graduate students, and both in Jordan and elsewhere. This implies that the exact level of knowledge of those students about CC and how agriculture can respond to it is not known. Consequently, gaps in knowledge of those students about CC and adaptation and mitigation practices are not known and, hence, the CC knowledge needs of this population are unclear. This study fills this knowledge gap. It aims at (i) assessing the level of knowledge of agricultural science master's students about $\mathrm{CC}$ and about how agriculture can mitigate it and adapt to it and (ii) identifying need for curricular reform, if any. Since the population of this study is agricultural science students, then emphasis in this investigation is paid to the mitigation and adaptation practices of agriculture, which they are supposed to know well.

\section{Method}

\subsection{Population}

This study is a quantitative cross-sectional survey of graduate students' knowledge of CC. The population of the study was agricultural science graduate students enrolled in the master's program of Climate Change, Sustainable Agriculture, and Food Security (CCSAFS), which is a program that is offered by the Faculty of Agricultural Sciences (FASs) in Jarash University, Jordan. This population was chosen because the majority of the master's students in this program are actually agriculture practitioners. Moreover, this program offers two directly-related compulsory CC courses: (i) Climate Change, Sustainable Agriculture, and Food Security (CCSAFS) and (ii) Climate Change and its Mitigation and Adaptation (CCMA). All program students join these two courses and are, consequently, anticipated to acquire advanced knowledge of $\mathrm{CC}$, its nature, causes, effects, mitigation, and adaptation. Additionally, this study took into account potential influence of those students on present and future climate mitigation and adaptation programs and activities in Jordan, particularly in the agricultural sector, bearing in mind that almost all of them are agricultural practitioners. The others are government officials working in agriculture-related organizations (e.g., the Ministry of Agriculture; the Ministry of Environment; and the Food and Drug Administration, Jordan).

\subsection{Sample}

In the time being, the total number of students enrolled in the CCSAFS master's program in the FASs is 57 students. The optimum sample size for this study was 50 students. It was computed according to the formula (Krejcie \& Morgan, 1970):

$$
n=\frac{\chi^{2 *} N^{*} P(1-P)}{d^{2 *}(N-1)+\chi^{2} * P(1-P)}
$$

where

$n$ : the sample size requirement.

$\chi^{2}$ : the square of the tabulated value of the Chi statistic $(\chi)$ for one degree of freedom at the desired level of confidence $(\alpha)$. In the present study, the desired value of $\alpha$ is 0.05 , corresponding to an error margin of $5.0 \%$. Accordingly, the $\chi^{2}$ statistic value is 3.8416 since $\chi=1.96$.

The degrees of freedom $(d f)$ are equal to the number of groups $(k)$ in the study minus 1 (Turhan, 2020):

$$
d f=k-1
$$

The number of groups in this study is two because the sample students categorize into two groups: 'Non-knowledgeable Students' and 'Knowledgeable Students'. Accordingly, $k$ is equal to 2, and, hence, the $d f$ equal 1.

$N$ : population size (57 agricultural science graduate students).

$P$ : proportion of successes in the population (usually, 0.50 ).

It is common practice to replace $P$, which is usually unknown, with 0.5 since this is the value which maximizes $(P-$ 1), that is, the value that produces the most conservative (i.e., largest) sample size (Hajian-Tilaki, 2011; Ramos et al., 2019). Therefore, 


$$
n=\frac{(1.96)^{2} * 57 * 0.50 *(0.50)}{(0.05)^{2} * 56+(1.96)^{2} * 0.50 *(0.50)}=49.75 \cong 50
$$

The 50 sample students were selected following the simple random sampling approach. The data collection process took about two weeks, extending from 4 July 2021 to 18 July 2021.

\subsection{Research Tool}

This study employed a test as the tool of choice for assessment of knowledge. The test was particularly designed by the researchers for the purpose of this study. It was designed and developed to serve as a comprehensive CC knowledge scale. To this end, it was composed of two major sections: (i) a demographic information section and (ii) a test section. The test section consisted of three sub-sections, each defining a construct (or sub-scale) of CC knowledge, that is, the (i) general knowledge of CC, which covers the nature, causes, and impacts of CC; (ii) agricultural practices of mitigation of $\mathrm{CC}$, and (iii) agricultural practices of adaptation to $\mathrm{CC}$. Each of these three sub-sections consisted of 15 true-false statements as will be shown in three tables later in the 'Results and Discussion' section. The general knowledge sub-scale probes factual (i.e., declarative) knowledge while the latter two sub-scales measure procedural (i.e., action-related) knowledge. They were particularly tailored to agriculture. This test can be described as a Climate Change Mitigation and Adaptation Knowledge Scale (CCMAKS). It was, then, made available to the target population online through the 'Google Docs' platform (https://docs.google.com/forms/d/e/1FAIpQLSeePyFNiPzEtQaK_ftXNZ8B2rrxVpe3eRZVXf_0RioCxPXC-w/viewf orm). All in all, this knowledge assessment test (CCMAKS) included statements of varying degrees of difficulty, ranging from knowledge that is covered by mass media and social communication networks to specialist's knowledge.

Content validity of the CCMAKS was examined. This type of validity evaluates the extent to which the items of the research tool adequately and representatively sample content of the field knowledge that is due to be measured. Development of a content-valid tool is typically made by rational analysis of it by experts who are quite knowledgeable about the construct and sub-constructs of interest or experts in the research theme (Bolarinwa, 2015; DeVon et al., 2013). In this respect, Boateng et al. (2018) underlined that content validity of the research tool is mainly evaluated through assessment by a panel of experts. Thereupon, the CCMAKS was subjected to content validation by three professors who are experts in assessment and evaluation and in CC teaching and research. The three judges assessed the test statements in terms of readability, relevance, clarity, accuracy, and interpretability. Based on the evaluation, the various test statements were modified to reasonably good survey design. There was high consensus among the three expert judges on that the CCMAKS corresponds to adequate and representative measurement of knowledge of CC. Merely few slight modifications to the first copy of the test were suggested.

\subsection{Statistical Analysis}

The research data were subjected to statistical analysis using the Statistical Package for Social Sciences (SPSS, v24.0). The demographic data of the respondents were analyzed using cross tabulation so as to obtain a description of the study sample. Frequency distribution analysis (FDA) was applied to the sentences of each sub-construct in an effort to assess the respondents' levels of knowledge of CC and of possible ways of CC mitigation and adaptation. Thereafter, the counts and percentages of the respondents relating to the individual statements of each of the three sub-constructs were averaged for the corresponding sub-construct so as to evaluate respondents' overall level of knowledge of that sub-construct.

\subsection{Knowledge Categorization}

To simplify interpretation of the FDA outcomes, the CC knowledge has been classified into three levels: low, moderate, and high, using the following equation (Paternoster \& Bachman, 2018):

$$
\begin{aligned}
\text { Interval Width } & =\frac{\text { Highest } \text { Score }- \text { Lowest Score }}{\text { Number of Classes }} \\
& =\frac{100 \%-0.0 \%}{3} \cong 33.3 \%
\end{aligned}
$$

Accordingly, the three levels of knowledge can be defined based on percentages of knowledgeable students as shown in Table 1. 
Table 1. Intervals Defining Levels of Knowledge

\begin{tabular}{lc}
\hline Knowledge level & Percentage of knowledgeable students \\
\hline Low & $<33.3$ \\
Moderate & $33.3-66.6$ \\
High & $>66.7$ \\
\hline
\end{tabular}

\section{Results and Discussion}

\subsection{Demographic Characteristics}

Cross tabulation (Table 2) shows that the study sample consisted of 14 female and 36 male agricultural science master's students. These counts correspond to $28.0 \%$ and $72.0 \%$ of the study sample, respectively. In terms of age, it is found that students ranging in age from 21 to 25 years were the highest in number $(n=13, \%=26.0 \%$ (Table 1$)$ ), followed by students belonging to the age group of 26-30 years $(11,22.0 \%)$. With the exception of students older than 50 years, who were the lowest in number $(2,4.0 \%)$, all other age groups have nearly equal representations in the study sample (5-7 students, 10.0-14.0\%). These results mean that the majority of the sample students were male students who are 30 years old or younger.

Table 2. Demographic Characteristics of the Sample Agricultural Science Graduate Students

\begin{tabular}{llccc}
\hline \multirow{2}{*}{ Age group } & & \multicolumn{2}{c}{ Gender } & \\
\cline { 2 - 4 } $21-25$ Years & Descriptor & Woman & Man & Total \\
\hline \multirow{3}{*}{$26-30$ Years } & \% of Total & $6.0 \%$ & $20.0 \%$ & 13 \\
& Count & 4 & 7 & $26.0 \%$ \\
$31-35$ Years & \% of Total & $8.0 \%$ & $14.0 \%$ & 11 \\
& Count & 1 & 4 & $22.0 \%$ \\
$36-40$ Years & \% of Total & $2.0 \%$ & $8.0 \%$ & 5 \\
& Count & 2 & 4 & $10.0 \%$ \\
$41-45$ Years & \% of Total & $4.0 \%$ & $8.0 \%$ & 6 \\
\multirow{3}{*}{$41-45$ Years } & Count & 2 & 5 & $12.0 \%$ \\
& \% of Total & $4.0 \%$ & $10.0 \%$ & 7 \\
$>50$ Years & Count & 0 & 6 & $14.0 \%$ \\
\multirow{2}{*}{ Total } & \% of Total & $0.0 \%$ & $12.0 \%$ & 6 \\
& Count & 2 & 0 & $12.0 \%$ \\
& \% of Total & $4.0 \%$ & $0.0 \%$ & 2 \\
\hline
\end{tabular}

\subsection{Knowledge Assessment}

The research tool (CCMAKS) consists of three main constructs: general knowledge of CC, knowledge of mitigation of $\mathrm{CC}$, and knowledge of adaptation to $\mathrm{CC}$. The general knowledge construct comprises three sub-constructs, namely, knowledge of the nature of CC (Statements 1-5), knowledge of causes of CC (Statements 6-10), and knowledge of effects of CC (Statements 11-15). As the FDA outcomes (Table 3) show, the sample master's students demonstrate a high level of knowledge of nature of CC since, on the average, almost $78.7 \%$ of them correctly answered all five statements of this sub-construct. The facets of nature of CC which the majority of the students know are that manifestations of CC vary from a climatic region to another $(98.0 \%)$ and that $\mathrm{CC}$ is overall bad $(90.0 \%)$. Meanwhile, the aspect of general knowledge of $\mathrm{CC}$ which is known by the least number of the students (18, $36.0 \%$ ) is that $\mathrm{CC}$ is more of man made than natural, which is a result that is against our expectations as faculty members in this master's program. Either these students did not read the statement well (Statement 1) or they hold the belief that there is no CC. 
Table 3. Graduate Students' General Knowledge of CC a

\begin{tabular}{|c|c|c|c|c|c|c|}
\hline \multirow[b]{3}{*}{ No. } & \multirow[b]{3}{*}{ Statement } & \multirow[b]{3}{*}{ Answer } & \multicolumn{4}{|c|}{ Responses } \\
\hline & & & \multicolumn{2}{|c|}{ Correct answer } & \multicolumn{2}{|c|}{ Wrong answer } \\
\hline & & & Freq. & $\% \mathbf{b}$ & Freq. & $\% b$ \\
\hline 1. & $\begin{array}{l}\text { Climate change is nothing but a natural fluctuation in } \\
\text { temperatures of the Earth }\end{array}$ & False & 32 & 64.0 & 18 & 36.0 \\
\hline 2. & $\begin{array}{l}\text { Manifestations of climate change vary from one } \\
\text { climatic region to another }\end{array}$ & True & 49 & 98.0 & 1 & 2.0 \\
\hline 3. & $\begin{array}{l}\text { It is very late for the human community to do anything } \\
\text { to stop climate change or control it }\end{array}$ & False & 36 & 72.0 & 14 & 28.0 \\
\hline 4. & $\begin{array}{l}\text { Agricultural activities like plant and animal production } \\
\text { contribute to climate change }\end{array}$ & True & 34 & 69.4 & 15 & 30.6 \\
\hline 5. & $\begin{array}{l}\text { Overall, climate change is bad; it is more harmful than } \\
\text { beneficial }\end{array}$ & True & 45 & 90.0 & 5 & 10.0 \\
\hline \multicolumn{2}{|c|}{ Nature of CC: Sub-construct average } & & 39 & 78.7 & 11 & 21.3 \\
\hline 6. & $\begin{array}{l}\text { Human activities do not tangibly affect temperatures of } \\
\text { the surface of the Earth }\end{array}$ & False & 49 & 98.0 & 1 & 2.0 \\
\hline 7. & Climate change primarily resulted from the ozone hole & False & 35 & 70.0 & 15 & 30.0 \\
\hline 8. & $\begin{array}{l}\text { The cause of climate change is the global warming } \\
\text { associated with the rise in concentrations of green house } \\
\text { gases in the atmosphere }\end{array}$ & True & 47 & 94.0 & 3 & 6.0 \\
\hline 9. & $\begin{array}{l}\text { The sector with the highest contribution to climate } \\
\text { change is the transportation sector }\end{array}$ & False & 26 & 52.0 & 24 & 48.0 \\
\hline 10. & $\begin{array}{l}\text { Environmental pollution resulting from the industry is } \\
\text { the principal cause of climate change }\end{array}$ & False & 8 & 16.0 & 42 & 84.0 \\
\hline \multicolumn{2}{|c|}{ Causes of CC: Sub-construct average } & & 33 & 66.0 & 17 & 34.0 \\
\hline 11. & $\begin{array}{l}\text { Climate change contributes to increased water and wind } \\
\text { erosion of soil }\end{array}$ & True & 47 & 95.9 & 2 & 4.1 \\
\hline 12. & $\begin{array}{l}\text { Decline in animal and plant food production, and, thus, } \\
\text { deterioration of food security, may result from climate } \\
\text { change }\end{array}$ & True & 47 & 94.0 & 3 & 6.0 \\
\hline 13. & $\begin{array}{l}\text { Climate change can result in shortage of water that is } \\
\text { suitable for household use and for irrigation of animals } \\
\text { and plants }\end{array}$ & True & 48 & 96.0 & 2 & 4.0 \\
\hline 14. & $\begin{array}{l}\text { Climate change reduces incidence of infectious and } \\
\text { contagious animal, plant, and human diseases }\end{array}$ & False & 43 & 86.0 & 7 & 14.0 \\
\hline 15. & $\begin{array}{l}\text { Manifestations of climate change include temporal } \\
\text { displacement of seasons, prolongation of some, and } \\
\text { shortening of others }\end{array}$ & True & 49 & 98.0 & 1 & 2.0 \\
\hline \multicolumn{2}{|c|}{ Effects of CC: Sub-construct average } & & 47 & 94.0 & 3 & 6.0 \\
\hline \multicolumn{2}{|c|}{ Construct average } & & 40 & 79.6 & 10 & 20.4 \\
\hline
\end{tabular}

a Any difference in number of respondents from 50 is due to missing value(s)

b Valid percentage, i.e., percentage of responses, excluding missing values 
Causes of CC were another investigated issue. The FDA results (Table 3) uncover that the sample students, on the average, have moderate knowledge of the causes of CC owing to that $66.0 \%$ of them could correctly judge on soundness of the five statements of this sub-construct. While the vast majority of these students know that human activities tangibly affect temperatures of the surface of the Earth $(98.0 \%)$ and that the cause of CC is the global warming $(94.0 \%)$, it is found that large proportion of these students $(84.0 \%)$ do not know that environmental pollution is a cause, but not the principal cause, of CC. As well, nearly half of the sample students (48.0\%) do not know that the transportation sector is not the sector with the highest contribution to CC. In other respects, nearly $30.0 \%$ of the sample graduate students have misconception of the position of the ozone hole in the CC mechanism. This confusion about location of the ozone hole in the CC process chain is not uncommon. Tobler et al. (2012) brought to notice that various earlier studies have disclosed varying misconceptions about $\mathrm{CC}$ which the general public holds, including the confusion about $\mathrm{CC}$ and ozone depletion. It is also surprising to find out that 15 of the sample students in the present study do not know that agricultural activities like plant and animal production contribute to CC though all of them already hold bachelor's degree in agricultural sciences.

The students' responses to Statement 1 contradict sharply with their responses to statements 6, 9, and 10, where the responses of more than half of the respondents to these three statements stress the human role in CC and that it is more of man-made process than natural phenomenon. This can be an indication of inconsistent knowledge of CC among these students. Another possible explanation is that they did not focus much while reading the test statements and judging on their soundness. Since participation in this study was voluntary and anonymous, then some of them might have not dealt with this test seriously and responsibly.

Effects of $\mathrm{CC}$ were another issue that was investigated. It is attracting attention that the sample students have high knowledge of effects of CC; on the average, almost $79.6 \%$ of them correctly answered the five related statements (Table 3). In fact, Table 3 points out that more than $94.0 \%$ of the students could correctly identify the effects of CC. The only exception is the association of infectious and contagious animal, plant, and human diseases with CC, which nearly $14.0 \%$ of the sample graduate students do not know about. In view of these findings, it is concluded that the faculty members in charge of teaching the CCSAFS and CCMA in general pay more attention to effects of CC than to its nature and causes.

Overall, it is found that the sample agricultural science graduate students have high level of knowledge of the nature, causes, and effects of CC. However, while they demonstrate high levels of knowledge of the nature and effects of $\mathrm{CC}$, they exhibit a moderate level of knowledge of its causes. The FDA outputs (Table 3) also pinpoint that these students lack knowledge about the relative contribution of industrial pollution to $\mathrm{CC}$, the sector contributing the most to CC (the transportation sector), and role of natural variability in CC. This suggests a need for re-evaluation of content of both the CCSAFS and CCMA courses to ensure reasonably sufficient coverage of the various knowledge gaps identified by this study, despite realizing the fact that not all these students are of good academic caliber and that they, therefore, vary in academic performance and achievement.

Mitigation of CC was a sub-construct that consisted in this study from 15 statements (Table 4). Analysis of the sample students' feedback on these statements discloses that their knowledge of agricultural mitigation of CC is moderate. Only $40.9 \%$ of them, on the average, provided right answers to the 15 statements. The analysis results can be summarized in three points:

1- The sample students have high level of knowledge of four mitigation measures (Table 4): substitution of fossil fuel with fuel derived from renewable resources (94.0\%); agroforestry $(89.6 \%)$; resorting to public, rather than private, transportation means (87.8\%); and reducing reliance on machinery in the agricultural works (72.9\%).

2- The sample students exhibit moderate level of knowledge of four mitigation practices (Table 4): avoiding burning animal and plant residues (66.0\%); replacing agricultural machinery and pumps that run on diesel with others that run on petrol $(44.9 \%)$; conservation tillage $(43.8 \%)$; and using hydrogen gas as a source of energy in the agricultural processes $(40.0 \%)$.

3- The sample students manifest low level of knowledge of seven mitigation practices (Table 4), three of which are related to reduced energy consumption (Statement 6 (percentage of students correctly judging on soundness of the statement is $12.8 \%)$, Statement $8(16.3 \%)$, and Statement $9(2.0 \%))$; three relate to reduced GHG emission (Statement 4 (8.2\%), Statement 7 (24.5\%), and Statement $14(6.1 \%)$ ); and one of which is relating to increased carbon sequestration (Statement $11(4.1 \%)$ ). 
Table 4. Graduate Students' Knowledge of Agricultural Measures of Mitigation of CC a

\begin{tabular}{|c|c|c|c|c|c|c|}
\hline \multirow[b]{3}{*}{ No. } & \multirow[b]{3}{*}{ Statement } & \multirow[b]{3}{*}{ Answer } & \multicolumn{4}{|c|}{ Responses } \\
\hline & & & \multicolumn{2}{|c|}{ Correct answer } & \multicolumn{2}{|c|}{ Wrong answer } \\
\hline & & & Freq. & $\%^{b}$ & Freq. & $\%{ }^{b}$ \\
\hline 1. & $\begin{array}{l}\text { Agroforestry represents one of the climate change } \\
\text { mitigation measures }\end{array}$ & True & 43 & 89.6 & 5 & 10.4 \\
\hline 2. & $\begin{array}{l}\text { Not burning animal and plant residues contributes to } \\
\text { mitigation of climate change }\end{array}$ & True & 33 & 66.0 & 17 & 34.0 \\
\hline 3. & $\begin{array}{l}\text { Substituting fossil fuels in agricultural operations with fuel } \\
\text { derived from renewable sources such as the Sun, wind, and } \\
\text { water falls contributes to mitigation of climate change }\end{array}$ & True & 47 & 94.0 & 3 & 6.0 \\
\hline 4. & $\begin{array}{l}\text { Organic farming is counted as one of the adaptation to } \\
\text { climate change actions }\end{array}$ & False & 4 & 8.2 & 45 & 91.8 \\
\hline 5. & $\begin{array}{l}\text { Reducing the reliance on machinery in the agricultural } \\
\text { works is considered as a climate change mitigation practice }\end{array}$ & True & 35 & 72.9 & 13 & 27.1 \\
\hline 6. & $\begin{array}{l}\text { The adaptation to climate change measures include the } \\
\text { production of fuel from plant and animal residues }\end{array}$ & False & 6 & 12.8 & 41 & 87.2 \\
\hline 7. & $\begin{array}{l}\text { Limiting the use of chemical fertilizers (inorganic } \\
\text { fertilizers) is an adaptation to climate change practice }\end{array}$ & False & 12 & 24.5 & 37 & 75.5 \\
\hline 8. & $\begin{array}{l}\text { Thermal insulation of agricultural buildings like barns, } \\
\text { warehouses, and farmers' and agricultural workers' } \\
\text { dwellings is categorized as a climate change adaptation } \\
\text { practice }\end{array}$ & False & 8 & 16.3 & 41 & 83.7 \\
\hline 9. & $\begin{array}{l}\text { Use of energy-saving (energy-efficient) tools, equipment, } \\
\text { and devices is a climate change adaptation action }\end{array}$ & False & 1 & 2.0 & 49 & 98.0 \\
\hline 10. & $\begin{array}{l}\text { Increased reliance of farmers and agricultural workers on } \\
\text { public transportation means and reduced reliance on their } \\
\text { private vehicles in their transport contributes to mitigation } \\
\text { of climate change }\end{array}$ & True & 43 & 87.8 & 6 & 12.2 \\
\hline 11. & $\begin{array}{l}\text { Planting trees, in general, and afforestation, in particular, are } \\
\text { counted as climate change adaptation practices }\end{array}$ & False & 2 & 4.1 & 47 & 95.9 \\
\hline 12. & $\begin{array}{l}\text { Use of hydrogen gas as a source of energy in the } \\
\text { agricultural processes is considered as a climate change } \\
\text { adaptation action }\end{array}$ & False & 19 & 40.0 & 28 & 59.6 \\
\hline 13. & $\begin{array}{l}\text { Replacing the agricultural machinery and pumps that run on } \\
\text { diesel with others that run on petrol (benzene) is one of the } \\
\text { climate change mitigation practices }\end{array}$ & True & 22 & 44.9 & 27 & 55.1 \\
\hline 14. & $\begin{array}{l}\text { Use of suitable air filters in the animal production farms } \\
\text { (animal houses and barns) and the similar closed farm } \\
\text { facilities is considered as a climate change adaptation } \\
\text { practice }\end{array}$ & False & 3 & 6.1 & 45 & 93.9 \\
\hline 15. & $\begin{array}{l}\text { The no tillage agricultural practice is classified as climate } \\
\text { change adaptation practice }\end{array}$ & False & 21 & 43.8 & 27 & 56.2 \\
\hline \multicolumn{2}{|c|}{ Construct average } & & 20 & 40.9 & 29 & 59.1 \\
\hline
\end{tabular}

a Any difference in number of respondents from 50 is due to missing value(s)

b Valid percentage, i.e., percentage of responses, excluding missing values 
The level of knowledge of the sample agricultural science students about mitigation of CC is somewhat shocking. Generally, their feedback on the 15 mitigation statements reflects inconsistency and contradiction. It is noticed that $94.0 \%$ of them know that CC is mitigated by substituting fossil fuels in agricultural operations with fuel derived from renewable sources. However, most of them do not know about the energy conservation practices addressed by statements $6,8,9,12$, and 13 . It can be inferred from the results (Table 4) that most of these students on the one hand lack knowledge of the nature and effects on ecosystem of the listed mitigation practices and, on the other hand, confuse certain mitigation practices with adaptation practices. It seems that not only the delicate consequences of the listed mitigation practices are not clear in the minds of these students, but also the direct consequences. This means that the intricate processes involved in the listed mitigation practices, and their indirect, and even direct, effects, are not known to these students. Thereupon, development of knowledge of the mechanisms and processes involved in these practices, besides their direct and indirect effects on ecosystem, should be stressed in future teaching of the agricultural science graduate students. The principles on which these practices stand should be a fundamental part of their university education.

Adaptation to CC was the third principal component of the present study. Frequency distribution analysis (Table 5) discloses that, in general, the sample agricultural science graduate students possess high level of knowledge of the agricultural practices of adaptation to CC. The average percentage of the sample master's students who provided correct answers to the 15 test statements is $72.4 \%$ and more than $83.0 \%$ of the sample students know about 10 of the listed adaptation practices (Table 5). Meantime, two adaptation practices are known by only $70.8 \%$ of the sample students, which are the use of genetically-engineered alternative crops and crop varieties (Statement 1) and integrated farming (Statement 12). On the other hand, three agricultural adaptation practices are known by much lower percentages of the sample students: employment of biotechnology and genetic engineering (Statement 11 $(14.3 \%)$ ), securing supplementary (new) water resources (Statement $5(16.3 \%)$ ), and growing cover crops (Statement $8(32.6 \%))$.

Discrepancy appears again in respondents' feedback on statements of this sub-construct. While the results (Table 5) show that $70.8 \%$ of the respondents know that replacing crop varieties with genetically-engineered alternatives is a $\mathrm{CC}$ adaptation action, about $85.7 \%$ of them do not know that employment of biotechnologies and genetic engineering in the agricultural operations is an adaptation. It appears that the majority of these students do not know what biotechnology and genetic engineering really are. This identifies a knowledge gap that may find roots in the current curricula of the CCSAFS master's program. In addition, while academic caliber and performance of some agricultural science graduate students is not that high, part of this discrepancy can be ascribed to the fact that participation in this study was voluntary and anonymous. This might have affected the degree of seriousness with which some of the participants dealt with the test. They might have not cared much about the final result of their test, and, in consequence, did not concentrate much while reading the test statements, which were of varying levels of difficulty; the CCMAKS, which is seemingly direct and simple, is somewhat arduous, not that plain or direct.

The researchers made an attempt to compare the findings of the current study with those of previous studies. However, literature search retrieved only one investigation of graduate students' knowledge of CC (Table 6), which is the study of Dalelo (2011). This researcher explored CC literacy of graduate students in four programs at Addis Ababa University in Ethiopia, with an attempt to cover all major geographical and conceptual aspects of CC literacy. The study sample included 91 students in the master's programs of Environmental Science, Geography and Environmental Studies, and Geography and Environmental Education. This researcher found that the sample students demonstrated slightly above average performance on the whole. However, they exhibited poor performance in some fundamental areas relating to the science behind CC, past trends in temperature and rainfall, and impact of CC on Africa. It is attracting attention that many of the students had low, or no, information about the actual and projected effects of CC on poor countries, including those in Africa. As well, the students' awareness of some of the principal measures proposed at global level was also non-satisfactory. However, even though the students in the present study seem far more knowledgeable of the CC nature, causes, effects, mitigation, and adaptation than the students in the study of Dalelo (2011), we can not jump to this sort of conclusion because the instruments used in these two studies are perfectly different. The instrument employed in the study of Dalelo (2011) is a knowledge test that addresses four facets of CC literacy; the CC basic science, causes, effects, and adaptation and mitigation measures. The CCMAKS addresses these issues, however, from perfectly different perspective and in a different way. 
Table 5. Graduate Students' Knowledge of Agricultural Measures of Adaptation to CC ${ }^{\text {a }}$

\begin{tabular}{|c|c|c|c|c|c|c|}
\hline \multirow[b]{3}{*}{ No. } & \multirow[b]{3}{*}{ Statement } & \multirow[b]{3}{*}{ Answer } & \multicolumn{4}{|c|}{ Responses } \\
\hline & & & \multicolumn{2}{|c|}{ Correct answer } & \multicolumn{2}{|c|}{ Wrong answer } \\
\hline & & & Freq. & $\% \mathbf{b}$ & Freq. & $\% b$ \\
\hline 1. & $\begin{array}{l}\text { Replacing the crop varieties to plant with genetically- } \\
\text { engineered alternatives represents a climate change } \\
\text { adaptation action }\end{array}$ & True & 34 & 70.8 & 14 & 29.2 \\
\hline 2. & $\begin{array}{l}\text { Irrigating plantations using the drip irrigation method is } \\
\text { categorized as an adaptation to climate change practice }\end{array}$ & True & 41 & 83.7 & 8 & 16.3 \\
\hline 3. & $\begin{array}{l}\text { Expanding the areas of green surfaces and establishing } \\
\text { new green surfaces like parks and gardens constitute } \\
\text { climate change adaptation practices }\end{array}$ & True & 46 & 93.9 & 3 & 6.1 \\
\hline 4. & $\begin{array}{l}\text { Diversification of crops in the same agricultural land } \\
\text { area is classified as a climate change adaptation } \\
\text { measure }\end{array}$ & True & 44 & 89.8 & 5 & 10.2 \\
\hline 5. & $\begin{array}{l}\text { One of the climate change mitigation practices is } \\
\text { securing supplementary water sources, e.g., by } \\
\text { exploration of new water wells }\end{array}$ & False & 8 & 16.3 & 41 & 83.7 \\
\hline 6. & $\begin{array}{l}\text { Planting drought-tolerant plant varieties represents an } \\
\text { adaptation to climate change }\end{array}$ & True & 49 & 98.0 & 1 & 2.0 \\
\hline 7. & $\begin{array}{l}\text { One of the adaptation to climate change practices is } \\
\text { selection of plant varieties having low water } \\
\text { requirement }\end{array}$ & True & 43 & 87.8 & 6 & 12.2 \\
\hline 8. & $\begin{array}{l}\text { The climate change mitigation practices include } \\
\text { planting cover crops such as legumes }\end{array}$ & False & 15 & 32.6 & 31 & 67.4 \\
\hline 9. & $\begin{array}{l}\text { Crop rotation represents a climate change adaptation } \\
\text { practice }\end{array}$ & True & 42 & 85.7 & 7 & 14.3 \\
\hline 10. & $\begin{array}{l}\text { In terms of its processes, procedures, and tools, } \\
\text { precision agriculture is classified as a climate change } \\
\text { adaptation action }\end{array}$ & True & 42 & 85.7 & 7 & 14.3 \\
\hline 11. & $\begin{array}{l}\text { Employment of biotechnologies and genetic } \\
\text { engineering in the agricultural operations is a practice } \\
\text { that aims at mitigating climate change }\end{array}$ & False & 7 & 14.3 & 42 & 85.7 \\
\hline 12. & $\begin{array}{l}\text { Integrated farming corresponds to a climate change } \\
\text { adaptation action }\end{array}$ & True & 34 & 70.8 & 14 & 29.2 \\
\hline 13. & $\begin{array}{l}\text { Water harvesting is a practice that categorizes as a } \\
\text { climate change adaptation measure }\end{array}$ & True & 41 & 85.4 & 7 & 14.6 \\
\hline 14. & $\begin{array}{l}\text { Enforcing the weather monitoring systems and } \\
\text { supporting them with early warning systems is an } \\
\text { adaptation action }\end{array}$ & True & 41 & 83.7 & 8 & 16.3 \\
\hline 15. & $\begin{array}{l}\text { Surrounding the sloping and non-sloping agricultural } \\
\text { lands with appropriate vegetative belts is a practice that } \\
\text { corresponds to adaptation to climate change }\end{array}$ & True & 43 & 87.8 & 6 & 12.2 \\
\hline \multicolumn{3}{|c|}{ Construct average } & 35 & 72.4 & 13 & 27.6 \\
\hline
\end{tabular}

a Any difference in number of respondents from 50 is due to missing value(s)

b Valid percentage, i.e., percentage of responses, excluding missing values 
Literature search retrieved many published studies of CC knowledge and awareness of undergraduate students (Table 6). While the list given in Table 6 is not an exclusive list of these studies, it presents the majority of the most relevant studies published in the English language over the past two decades. It should be spotlighted that we think that it is not much sound or meaningful to hold comparisons between the results of such studies and the results of the present study because the population of the present study is master's students of agricultural sciences specializing in CCSAFS. On this account, these students are mostly much more knowledgeable of CC than undergraduate students. Consequently, the researchers think that the present study and the study of Dalelo (2011) provide baseline data on $\mathrm{CC}$ knowledge of master's students and they, hence, will serve - for many years to come - as key reference for similar future investigations.

Table 6. Examples of Previous Investigations of Climate Change Knowledge of University Students ${ }^{1}$

\begin{tabular}{|c|c|c|c|c|c|c|c|c|c|c|c|}
\hline \multirow[b]{2}{*}{ Reference } & \multirow[b]{2}{*}{ Country } & \multicolumn{4}{|c|}{ Sample university students } & \multicolumn{6}{|c|}{ Climate change facet investigated } \\
\hline & & Undergraduate & Graduate & $\begin{array}{l}\text { University/C } \\
\text { ollege }\end{array}$ & Faculty & $\begin{array}{l}\text { General } \\
\text { knowledge }\end{array}$ & Nature & Causes & Effects & Mitigation & Adaptation \\
\hline $\begin{array}{l}\text { Gazzaz and } \\
\text { Aldeseet } \\
(2021)\end{array}$ & Jordan & $\sqrt{ }$ & $\mathrm{X}$ & $\begin{array}{l}\text { Jarash } \\
\text { Private } \\
\text { University }\end{array}$ & $\begin{array}{l}\text { - Agricultural } \\
\text { Sciences } \\
\text { - Physical } \\
\text { Sciences }\end{array}$ & $\mathrm{X}$ & $\sqrt{ }$ & $\sqrt{ }$ & $\sqrt{ }$ & $\mathrm{X}$ & $\mathrm{X}$ \\
\hline $\begin{array}{l}\text { La Torre et } \\
\text { al. }(2020)\end{array}$ & Italy & $\sqrt{ }$ & $\mathrm{X}$ & $\begin{array}{l}\text { Sapienza } \\
\text { University } \\
\text { of Rome }\end{array}$ & $\begin{array}{l}\text { - Medicinal } \\
\text { Science } \\
\text { - Allied } \\
\text { Medicinal } \\
\text { Sciences }\end{array}$ & $\mathrm{x}$ & $\mathrm{X}$ & $\sqrt{ }$ & $\sqrt{ }$ & $\mathrm{X}$ & $\mathrm{x}$ \\
\hline $\begin{array}{l}\text { Akrofi et } \\
\text { al. (2019) }\end{array}$ & Algeria & $\sqrt{ }$ & $\mathrm{x}$ & $\begin{array}{l}\text { University } \\
\text { of Tlemcen }\end{array}$ & $\begin{array}{l}\text { All university } \\
\text { faculties }\end{array}$ & $\mathrm{x}$ & $\sqrt{ }$ & $\sqrt{ }$ & $\sqrt{ }$ & $\mathrm{x}$ & $\mathrm{x}$ \\
\hline $\begin{array}{l}\text { Barreda } \\
(2018)\end{array}$ & $\begin{array}{l}\text { The } \\
\text { Philippines }\end{array}$ & $\sqrt{ }$ & $\mathrm{X}$ & $\begin{array}{l}\text { Partido State } \\
\text { University }\end{array}$ & $\begin{array}{l}\text { All university } \\
\text { faculties }\end{array}$ & $\sqrt{ }$ & $\mathrm{X}$ & $\mathrm{X}$ & $\mathrm{X}$ & $\mathrm{X}$ & $\mathrm{X}$ \\
\hline $\begin{array}{l}\text { Mugambiw } \\
\text { a and } \\
\text { Dzomonda } \\
\text { (2018) }\end{array}$ & South Africa & $\sqrt{ }$ & $\mathrm{x}$ & $\begin{array}{l}\text { University } \\
\text { of Limpopo }\end{array}$ & $\begin{array}{l}\text { - Health } \\
\text { Sciences } \\
\text { - Human } \\
\text { Sciences } \\
\text { - Science and } \\
\text { Agriculture }\end{array}$ & $\sqrt{ }$ & $\mathrm{X}$ & $\sqrt{ }$ & $\sqrt{ }$ & $\mathrm{X}$ & $\mathrm{x}$ \\
\hline $\begin{array}{l}\text { Ogunsola, } \\
\text { Araromi, } \\
\text { and } \\
\text { Adeshina } \\
\text { (2018) }\end{array}$ & Nigeria & $\sqrt{ }$ & $\mathrm{x}$ & $\begin{array}{l}\text { - University } \\
\text { of Ibadan }\end{array}$ & $\begin{array}{l}\text { All university } \\
\text { faculties }\end{array}$ & $\mathrm{x}$ & $\sqrt{ }$ & $\sqrt{ }$ & $\sqrt{ }$ & $\mathrm{X}$ & $\mathrm{x}$ \\
\hline $\begin{array}{l}\text { Yang et al. } \\
(2018)\end{array}$ & China & $\sqrt{ }$ & $\mathrm{x}$ & $\begin{array}{l}\text { - Harbin } \\
\text { Medical } \\
\text { University } \\
\text { - Sichuan } \\
\text { University - } \\
\text { Sun Yat-sen } \\
\text { University } \\
\text { - Fujian } \\
\text { Medical } \\
\text { University } \\
\text { - Huazhong } \\
\text { University } \\
\text { of Science } \\
\text { and } \\
\text { Technology }\end{array}$ & $\begin{array}{l}\text { - Medicinal } \\
\text { Science } \\
\text { - Nursing } \\
\text { Sciences } \\
\text { - Public Health }\end{array}$ & $\mathrm{x}$ & $\sqrt{ }$ & $\sqrt{ }$ & $\sqrt{ }$ & $\sqrt{ }$ & $\sqrt{ }$ \\
\hline
\end{tabular}

1 As regards the investigations of undergraduate students' knowledge of CC, the list presented in Table 6 is not exclusive or exhaustive; several published works were excluded being not tightly-related to the theme and scope of the present study. 
Table 6. Examples of Previous Investigations of Climate Change Knowledge of University Students ${ }^{1}$ (Continued)

\begin{tabular}{|c|c|c|c|c|c|c|c|c|c|c|c|}
\hline \multirow[b]{2}{*}{ Reference } & \multirow[b]{2}{*}{ Country } & \multicolumn{4}{|c|}{ Sample university students } & \multicolumn{6}{|c|}{ Climate change facet investigated } \\
\hline & & Undergraduate & Graduate & $\begin{array}{l}\text { University } \\
\text { /College }\end{array}$ & Faculty & $\begin{array}{l}\text { General } \\
\text { knowledge }\end{array}$ & Nature & Causes & Effects & Mitigation & Adaptation \\
\hline $\begin{array}{l}\text { Arto-Blanco } \\
\text { and } \\
\text { Meira-Cartea } \\
\text { (2017) }\end{array}$ & $\begin{array}{l}\text { - Mexico } \\
\text { - Spain }\end{array}$ & $\sqrt{ }$ & $\mathrm{X}$ & $\begin{array}{l}\text { Miscellan } \\
\text { eous }\end{array}$ & $\begin{array}{l}\text { - Educational } \\
\text { Sciences } \\
\text { - Engineering } \\
\text { Sciences } \\
\text { - Physical } \\
\text { Sciences } \\
\text { - Social and } \\
\text { Human } \\
\text { Sciences }\end{array}$ & $\sqrt{ }$ & $\mathrm{X}$ & $\sqrt{ }$ & $\mathrm{x}$ & $\mathrm{X}$ & $\mathrm{X}$ \\
\hline $\begin{array}{l}\text { Zerrudo, } \\
\text { Salain, and } \\
\text { Salain (2017) }\end{array}$ & $\begin{array}{l}\text { The } \\
\text { Philippine } \\
\text { s }\end{array}$ & $\sqrt{ }$ & $\mathrm{X}$ & $\begin{array}{l}\text { Basilan } \\
\text { State } \\
\text { College }\end{array}$ & $\begin{array}{l}\text { - Arts } \\
\text { - Community } \\
\text { Nutrition } \\
\text { - Educational } \\
\text { Sciences } \\
\text { - Nursing } \\
\text { Sciences } \\
\text { - Physical } \\
\text { Sciences } \\
\text { - Social } \\
\text { Sciences }\end{array}$ & $\mathrm{X}$ & $\mathrm{X}$ & $\mathrm{x}$ & $\mathrm{x}$ & $\sqrt{ }$ & $\sqrt{ }$ \\
\hline $\begin{array}{l}\text { Agboola and } \\
\text { Emmanuel } \\
(2016)\end{array}$ & Nigeria & $\sqrt{ }$ & $\mathrm{X}$ & $\begin{array}{l}\text { - } \\
\text { University } \\
\text { of Ibadan } \\
\text { - Ladoke } \\
\text { Akintola } \\
\text { University } \\
\text { of } \\
\text { Technolo } \\
\text { gy }\end{array}$ & $\begin{array}{l}\text { All university } \\
\text { faculties }\end{array}$ & $\sqrt{ }$ & $\sqrt{ }$ & $\mathrm{x}$ & $\sqrt{ }$ & $\mathrm{x}$ & $\mathrm{X}$ \\
\hline $\begin{array}{l}\text { Ojomo, Elliott, } \\
\text { Amjad, and } \\
\text { Bartram } \\
(2015)\end{array}$ & Nigeria & $\sqrt{ }$ & $\mathrm{X}$ & $\begin{array}{l}- \\
\text { University } \\
\text { of Lagos } \\
\text { - } \\
\text { University } \\
\text { of Uyo }\end{array}$ & $\begin{array}{l}\text { - Engineering } \\
\text { Sciences } \\
\text { - } \\
\text { Environmental } \\
\text { Sciences } \\
\text { - Law }\end{array}$ & $\sqrt{ }$ & $\mathrm{x}$ & $\mathrm{x}$ & $\sqrt{ }$ & $\mathrm{x}$ & $\mathrm{X}$ \\
\hline $\begin{array}{l}\text { Oruonye } \\
(2011)\end{array}$ & Nigeria & $\sqrt{ }$ & $\mathrm{X}$ & $\begin{array}{l}\text { - Taraba } \\
\text { State } \\
\text { University } \\
\text { - Taraba } \\
\text { State } \\
\text { Polytechn } \\
\text { ic }\end{array}$ & $\begin{array}{l}\text { - Educational } \\
\text { Sciences }\end{array}$ & $\sqrt{ }$ & $\mathrm{x}$ & $\mathrm{x}$ & $\sqrt{ }$ & $\mathrm{x}$ & $\mathrm{X}$ \\
\hline
\end{tabular}

1 As regards the investigations of undergraduate students' knowledge of CC, the list presented in Table 6 is not exclusive or exhaustive; several published works were excluded being not tightly-related to the theme and scope of the present study. 
Table 6. Examples of Previous Investigations of Climate Change Knowledge of University Students ${ }^{1}$

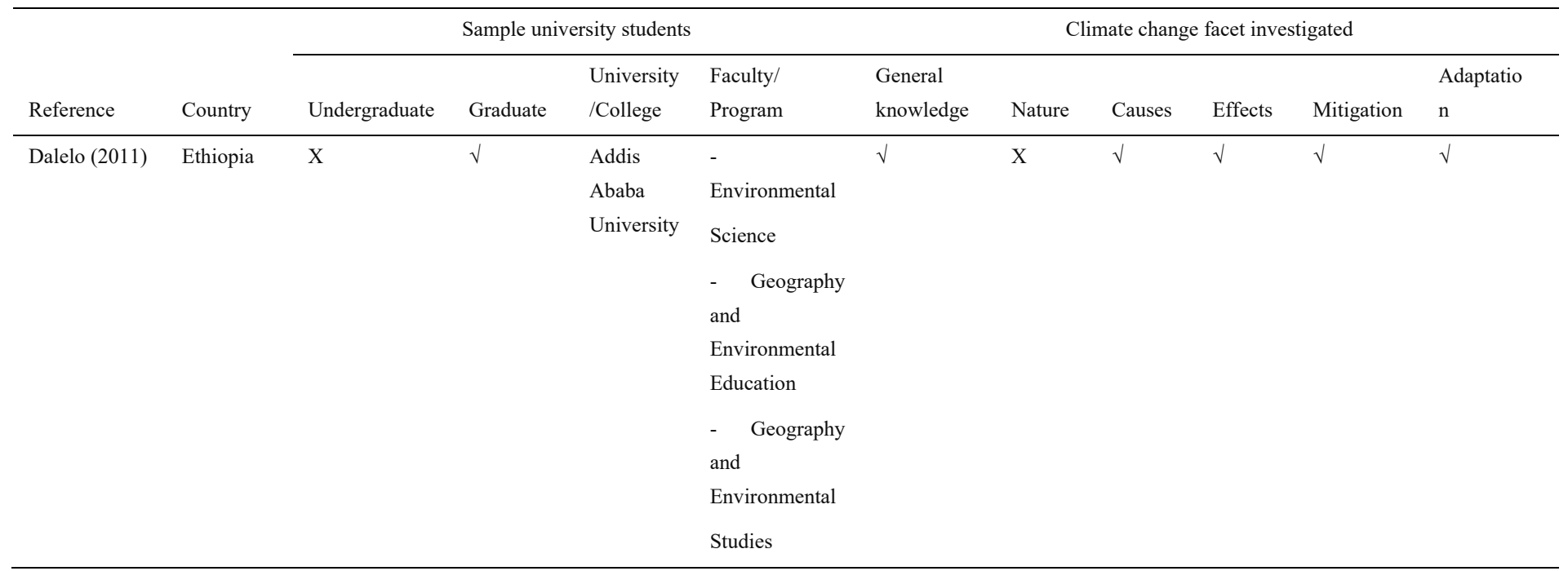

1 As regards the investigations of undergraduate students' knowledge of CC, the list presented in Table 6 is not exclusive or exhaustive; several published works were excluded being not tightly-related to the theme and scope of the present study.

However, from an educational perspective, the results of the current study flow in harmony with results of some previous studies in that a need for curriculum reform is identified. The present study found that the sample agricultural science master's students have limited understanding of CC-related processes and actions that involve complex pathways and that they hold various misconceptions related to $\mathrm{CC}$, in spite of the fact that, on the average, they have high knowledge of the CC nature, causes, effects, and adaptation. This finding brings to light the argument of Molthan-Hill et al. (2019) that CCESD is prone to the problem that some institutions and academics favor to focus more on less than more complex topics within the ESD framework. The results of the study of Cordero, Todd, and Abellera (2008) too pinpointed profound misconceptions about CC among university students. These researchers too identified a need for CC curricula reform and stressed on introduction of effective, action-oriented learning activities. Likewise, Ayanlade and Jegede (2016) discovered a need for introduction of CC studies in Nigerian universities since more than $71.0 \%$ of their sample university graduates mentioned that $\mathrm{CC}$ studies should be incorporated into university education as compulsory course(s), both in the undergraduate and postgraduate studies. Moreover, Competente (2019) researched into attitudes of pre-service teachers towards CCE and potential inclusion of it in their future teaching. He reported that the sample teachers had low awareness on CC and certain misconceptions of it. In view of the study results, he underlined a need for the university curricula to supply the students with activities to raise their CC awareness. The study of Filho et al. (2021) is particularly noteworthy. Based on analysis of how universities in 45 countries handle CCE, these researchers reached to the conclusion that not all the universities are fully prepared for addressing CC in the curricula and that further improvements are in effect needed. Indeed, there is a need for development of curricula that add the most suitable $\mathrm{CC}$ mitigation and adaptation measures and practices to each discipline (Molthan-Hill et al., 2019). Additionally, the plans and programs set for promoting adaptation and mitigation require multidisciplinary approaches (Filho et al., 2021). In view of this, the researchers in the present study maintain that, as far as CCESD is concerned, the curricula development process ought to address the multidisciplinary nature of this topic and, thereupon, the curricula development team itself should be multidisciplinary in nature, integrating specialists and experts in physical sciences, agricultural sciences, educational sciences, and social sciences.

\section{Conclusions}

This study analyzed the level of knowledge of agricultural science graduate students about CC, with emphasis on mitigation and adaptation practices of agriculture, in an effort to assess the extent to which these students can, and are prepared to, take active role in CC mitigation and adaptation efforts. One associated objective was to develop comprehensive CC knowledge scale (the CCMAKS) that can be employed in similar future research. The scale was designed in such a way as to cover a wide spectrum of the domains of the climate-related knowledge (the CC nature, causes, effects, mitigation, and adaptation) and to include questions of varying levels of difficulty. 
The analysis unveiled that the agricultural science graduate students possess high level of general knowledge of CC (nature, causes, and effects), moderate level of knowledge of agricultural mitigation of CC, and high level of knowledge of agricultural adaptation to CC. Moreover, these students have high levels of knowledge of the effects and the nature of $\mathrm{CC}$ and moderate level of knowledge of its causes. Based on these findings, it is concluded that these students have limited understanding of CC-related issues, actions, and practices involving somewhat sophisticated pathways. In addition, our findings point out that the agricultural science master's students hold various misconceptions related to $\mathrm{CC}$, in spite of the fact that, on the average, they have high knowledge of the CC nature, causes, effects, and adaptation. In light of this, it is concluded that there is margin for improvement of the CC knowledge of these students and their future peers through curricular reform.

A higher level of knowledge of the causes of CC can lead to enhanced awareness of CC mitigation in the agricultural sector. Even though the good understanding of the nature, causes, and impacts of CC is quite important, it is not adequate to get the agricultural science graduate students prepared to respond to CC and its consequences. Since people's knowledge of $\mathrm{CC}$ can affect success of $\mathrm{CC}$ mitigation and adaptation initiatives and programs, the herein identified gaps in knowledge call for prompt action. Appropriate interventions are badly needed. Teaching of the guiding principles and the underlying mechanisms of CC mitigation and adaptation needs to be further strengthened. This will improve CC learning and create appropriate understanding and sufficient knowledge of how to mitigate CC and adapt to it in the agricultural sector. Further, as Filho et al. (2021) indicated, effects of CC go across broad range of disciplines. Thereupon, it is highly important for curricula and instructors to take this issue into consideration as part of CC teaching and research programs of universities to support deep learning of CC. A shift towards actionoriented teaching and learning is particularly recommended.

The graduate students are good change agents once their knowledge base is well established. Several gaps in knowledge of the agricultural science graduate students have been identified, especially the causes of $\mathrm{CC}$ and the practices through which agriculture can mitigate it. On this account, the CC core courses in the agricultural science master's program of CCSAFS need to be re-constructed in such a way as to ensure that the knowledge gaps identified by this investigation are filled. The $\mathrm{CC}$ agricultural mitigation and adaptation practices, in addition to the causes, mechanism, processes, and pathways of $\mathrm{CC}$, should be further integrated into the current curricula, particularly in the two core courses CCSAFS and CCMA, while the involved faculty members should be encouraged to address these knowledge gaps and focus on expanded coverage of the corresponding new course content.

Dissemination of knowledge is highly important for ensuring that knowledge grows and spreads amongst the various stakeholders and that it is turned into action. The students of today are the leaders and policy makers of tomorrow. They will effectively serve as change agents once their knowledge base has been well established. Albeit knowledge does not all the time translate into action, it is a prerequisite for taking action, and the effective $\mathrm{CC}$ actions require sound knowledge. In effect, knowledge about how agriculture can mitigate $\mathrm{CC}$ and adapt to it can be the most powerful driver of adoption of mitigation and adaptation practices and involvement in mitigation and adaptation initiatives and programs at the country level. In consequence, extension of CC education beyond its most popular aspects of nature, causes, and effects is highly recommended for the agricultural science university students, in general, and the agricultural science graduate students, in particular.

\section{Acknowledgments}

The researchers sincerely thank Prof. Ali J. Al-Sharafat (Jarash University, Jordan), Prof. Ihab H. Ghabeish (Balqa University for Applied Sciences, Jordan), and Prof. Mahmoud M. Abu-Allaban (The Hashemite University, Jordan) for their kind referring of the research tool. Their valuable comments and suggestions contributed much to validity and reliability of the research instrument, credibility of the study, and integrity of its outcomes.

\section{References}

Agboola, O. S., \& Emmanuel, M. (2016). Awareness of climate change and sustainable development among undergraduates from two selected universities in Oyo State, Nigeria. World Journal of Education, 6(3), 70-81. https://doi.org/10.5430/wje.v6n3p70

Akrofi, M. M., Antwi, S. H., \& Gumbo, J. R. (2019). Students in climate action: A study of some influential factors and implications of knowledge gaps in Africa. Environments, 6(12), 1-15. https://doi.org/10.3390/environments6020012 
Anderson, A. (2012). Climate change education for mitigation and adaptation. Journal of Education for Sustainable Development, 6(2), 191-206. https://doi.org/10.1177/0973408212475199

Apata, T. G. (2011). Effects of global climate change on Nigerian agriculture: An empirical analysis. CBN Journal of Applied Statistic, 2(1), 31-50. https://doi.org/10.22004/ag.econ.91751

Arto-Blanco, M., \& Meira-Cartea, P. Á. (2017). Climate literacy among university students in Mexico and Spain: influence of scientific and popular culture in the representation of the causes of climate change. International Journal of Climate Change, 12(3/4), 448-467. https://doi.org/10.1504/IJGW.2017.10005896

Asrat, P., \& Simane, B. (2018). Farmers' perception of climate change and adaptation strategies in the Dabus watershed, North-West Ethiopia. Ecological Processes, 7(7), 2-13. https://doi.org/10.1186/s13717-018-0118-8

Atube, F., Malinga, G. M., Nyeko, M., Okello, D. M., Alarakol, S. P., \& Okello-Uma, I. (2021). Determinants of smallholder farmers' adaptation strategies to the effects of climate change: Evidence from northern Uganda. Agriculture \& Food Security, 10(6), 1-14. https://doi.org/10.1186/s40066-020-00279-1

Ayanlade, A., \& Jegede, M.O. (2016). Climate change education and knowledge among Nigerian university graduates. Weather, Climate, and Society, 8(4), 465-473. https://doi.org/10.1175/WCAS-D-15-0071.1

Baer, A. P., Sestili, C., Cocchiara, R. A., Barbato, D., Del Cimmuto A., \& La Torre, G. (2019). Perception of climate change: Validation of a questionnaire in Italy. Clinical Therapeutics, 170(3), e184-191. https://doi.org/10.7417/CT.2019.2131

Barkmann, T., Siebert, R., \& Lange, A. (2017). Land-use experts' perception of regional climate change: An empirical analysis from the North German Plain. Climatic Change, 144, 287-301. https://doi.org/10.1007/s10584-017-2041-x

Barreda, A. B. (2018). Assessing the level of awareness on climate change and sustainable development among students of Partido State University, Camarines Sur, Philippines. Journal of Sustainability Education, 17, 1-17. https://doi.org/10.13140/rg.2.2.25047.29601

Boakye, C. (2015). Climate change education: The role of pre-tertiary science curricula in Ghana. SAGE Open, 5(4), 1-10. https://doi.org/10.1177/2158244015614611

Boateng, G. O., Neilands, T. B., \& Frongillo, E. A. (2018). Best practices for developing and validating scales for health, social, and behavioral research: A primer. Frontiers in Public Health, 6(149), 1-18. https://doi.org/10.3389/fpubh.2018.00149

Bolarinwa, O. A. (2015). Principles and methods of validity and reliability testing of questionnaires used in social and health science researches. Nigerian Postgraduate Medical Journal, 22(4), 195-201. https://doi.org/10.4103/1117-1936.173959

Competente, R. J. T. (2019). Pre-service teachers' inclusion of climate change education. International Journal of Evaluation and Research in Education, 8(1), 119-126. http://iaescore.com/journals/index.php/IJERE

Cordero, E. C., Todd, A. M., \& Abellera, D. (2008). Climate change education and the ecological footprint. Bulletin of the American Meteorological Society, 89(6), 865-872. https://doi.org/10.1175/2007BAMS2432.1

Crowley, T. J. (2000). Causes of climate change over the past 1000 years. Science, 289(5477), 270-277. https://doi.org/10.1126/science.289.5477.270

Dalelo, A. (2011). Climate change literacy among postgraduate students of Addis Ababa University, Ethiopia. Southern African Journal of Environmental Education, 28, 85-104.

DeVon, H. A., Block, M. E., Moyle-Wright, P., Ernst, D. M., Hayden, S. J., Deborah J. ... Kostas-Polston, E. (2007). A psychometric toolbox for testing validity and reliability. Journal of Nursing Scholarship, 39(2), 155-64. https://doi.org/10.1111/j.1547-5069.2007.00161.x

Dhanya, P., \& Ramachandran, A. (2016). Farmers' perceptions of climate change and the proposed agriculture adaptation strategies in a semi arid region of south India. Journal of Integrative Environmental Science, 13(1), 1-18. https://doi.org/10.1080/1943815X.2015.1062031

Duguma, L. A., Minang, P. A., \& van Noordwijk, M. (2014). Climate change mitigation and adaptation in the land use sector: From complementarity to synergy. Environmental Management, 54(3), 420-432. https://doi.org/10.1007/s00267-014-0331-x 
Easton, Z. M., \& Faulkner, J. W. (2014). Climate change adaptation for agriculture: Mitigating short- and long-term impacts of climate on crop production. Virginia Cooperative Extension. Retrieved from https://www.pubs.ext.vt.edu/content/dam/pubs_ext_vt_edu/BSE/BSE-109/BSE-109-PDF.pdf

Esham, M., \& Garforth, C. (2013). Agricultural adaptation to climate change: Insights from a farming community in Sri Lanka. Mitigation and Adaptation Strategies for Global Change, 18(5), 535-549. https://doi.org/10.1007/s11027-012-9374-6

Falaye, F. V., \& Okwilagwe, E. A. (2016). Assessing the senior school students' knowledge, attitude and practices related to climate change: Implications for curriculum review and teacher preparation. Journal of the International Society for Teacher Education, 20(1), 43-53.

Fawzy, S., Osman, A. I., Doran, J., \& Rooney, D. W. (2020). Strategies for mitigation of climate change: A review. Environmental Chemistry Letters, 18(6), 2069-2094. https://doi.org/10.1007/s10311-020-01059-w

Filho, W. L., Sima, M., Sharifi, A., Luetz, J. M., Salvia, A. L., Mifsud, M., ... \& Lokupitiya, E. (2021). Handling climate change education at universities: An overview. Environmental Sciences Europe, 33(109), 1-19. https://doi.org/10.1186/s12302-021-00552-5

Frigg, R., Thompson, E., \& Wernd, C. (2015). Philosophy of climate science. Part I: Observing climate change. Philosophy Compass, 10(12), 953-964. https://doi.org/10.1111/phc3.12294

Gazzaz, N. M., \& Aldeseet, B. A. (2021). Assessment of the level of knowledge of climate change of undergraduate science and agriculture students. World Journal of Education, 11(5), 41-60. https://doi.org/10.5430/wje.v11n5p41

Goh, K. M. (2011). Greater mitigation of climate change by organic than conventional agriculture: A review. Biological Agriculture \& Horticulture, 27(2), 205-229. https://doi.org/10.1080/01448765.2011.9756648

Haden, V. R., Niles, M. T., Lubell, M., Perlman, J., \& Jackson, L. E. (2012). Global and local concerns: What attitudes and beliefs motivate farmers to mitigate and adapt to climate change? PLOS ONE, 7(12), e52882. https://doi.org/10.1371/journal.pone.0052882

Hajian-Tilaki, K. (2011). Sample size estimation in epidemiologic studies. Caspian Journal of Internal Medicine, 2(4), 289-298.

Hulme, M., Dessai, S., Lorenzoni, I., \& Nelson, D.R. (2009). Unstable climates: Exploring the statistical and social constructions of climate. Geoforum, 40(2), 197-206. https://doi.org/10.1016/j.geoforum.2008.09.010

Hussain, M., Butt, A., Uzma, F., Ahmed, R., Irshad, S., Abdul Rehman \& Yousaf, B. (2020). A comprehensive review of climate change impacts, adaptation, and mitigation on environmental and natural calamities in Pakistan. Environmental Monitoring and Assessment, 192(48), 1-20. https://doi.org/10.1007/s10661-019-7956-4

IPCC (2014). Climate change 2014: Synthesis report. The Intergovernmental Panel on Climate Change. Retrieved from https://www.ipcc.ch/site/assets/uploads/2018/02/SYR_AR5_FINAL_full.pdf

Jørgensen, S. L., \& Termansen, M. (2016). Linking climate change perceptions to adaptation and mitigation action. Climatic Change, 138(1), 283-296. https://doi.org/10.1007/s10584-016-1718-x

Kakaki, S. (2013). Climate change: Its causes, effects and control. Journal of Educational and Social Research, 3(10), 73-77. https://doi.org/10.5901/jesr.2013.v3n10p73

La Torre, G., Baer, A. D. P., Sestili, C., Cocchiara, R. A., Barbato, D., Mannocci, A., \& Del Cimmuto, A. (2020). Knowledge and perception about climate change among healthcare professionals and students: A cross-sectional study. South Eastern European Journal of Public Health, XIII, 1-19. https://doi.org/10.4119/seejph-3347

Limantol, A. M., Keith, B. E., Azabre, B. A., \& Lennartz, B. (2016). Farmers' perception and adaptation practice to climate variability and change: A case study of the Vea catchment in Ghana. SpringerPlus, 5(830), 1-38. https://doi.org/10.1186/s40064-016-2433-9

Lineman, M., Do, Y., Kim, J. Y., \& Joo, G. (2015). Talking about climate change and global warming. PLOS ONE, 10(9), e0138996. https://doi.org/10.1371/journal.pone.0138996

Liu, W., Liu, L., \& Gao, J. (2020). Adapting to climate change: Gaps and strategies for Central Asia. Mitigation and Adaptation Strategies for Global Change, 25(8), 1439-1459. https://doi.org/10.1007/s11027-020-09929-y 
Lynch, J., Cain, M., Frame, D., \& Pierrehumbert, R. (2021). Agriculture's contribution to climate change and role in mitigation is distinct from predominantly fossil $\mathrm{CO}_{2}$-emitting sectors. Frontiers in Sustainable Food Systems, 4(518039), 1-9. https://doi.org/10.3389/fsufs.2020.518039

Marty, R., \& Yokochi, R. (2006). Water in the early earth. Reviews in Mineralogy \& Geochemistry, 62(1), $421-450$. http://dx.doi.org/10.2138/rmg.2006.62.18

Mkonda, M. Y., He, X., \& Festin, E. S. (2018). Comparing smallholder farmers' perception of climate change with meteorological data: Experience from seven agroecological zones of Tanzania. Weather, Climate, and Society, 10(3), 435-452. https://doi.org/10.1175/WCAS-D-17-0036.1

Marangoni, G., Lamontagne, J. R., Quinn, J. D., Reed, R. M., \& Keller, K. (2021). Adaptive mitigation strategies hedge against extreme climate futures. Climatic Change, 166(37), 1-17. https://doi.org/10.1007/s10584-021-03132-X

Molthan-Hill, P., Worsfold, N., Nagy, G. J., Filho, W. L., \& Mifsud, M. (2019). Climate change education for universities: A conceptual framework. Journal of Cleaner Production, 226(21), 1092-1101. https://doi.org/10.1016/j.jclepro.2019.04.053

Mukhopadhyay, B. (2020). Entwining climate change adaptation and mitigation with development. International Journal of Research in Engineering, Science and Management, 3(1), 150-155.

Mugambiwa, S. S., \& Dzomonda, O. (2018). Climate change and vulnerability discourse by students at a South African university. Jàmbá: Journal of Disaster Risk Studies, $10(1), \quad$ a476. https://doi.org/10.4102/jamba.v10i1.476

Niles, M. (2008). Sustainable soils: Reducing, mitigating, and adapting to climate change with organic agriculture. Sustainable Development Law and Policy, 9(1), 19-23. https://doi.org/10.6084/m9.figshare.1569552.v1

Niles, M. T., Brown, M., \& Dynes, R. (2016). Farmer's intended and actual adoption of climate change mitigation and adaptation strategies. Climatic Change, 135(2), 277-295. http://dx.doi.org/10.1007/s10584-015-1558-0

Odjugo, P. A. O. (2010). General overview of climate change impacts in Nigeria. Journal of Human Ecology, 29(1), 47-55. https://doi.org/10.1080/09709274.2010.11906248

Ogunsola, O. E., Araromi, O. I., \& Adeshina, O. A. (2018). Studies on students' awareness on climate change education in Nigeria: A case study of the University of Ibadan. Journal of Emerging Trends in Educational Research and Policy Studies, 9(6), 251-257.

Ojomo, E., Elliott, M., Amjad, U., \& Bartram, J. (2015). Climate change preparedness: A knowledge and attitudes study in southern Nigeria. Environments, 2(4), 435-448. https://doi.org/10.3390/environments2040435

Olaniyi, O. A., Funmilayo, O. A., \& Olutimehin, I. O. (2014). Review of climate change and its effect on Nigeria ecosystem. International Journal of Environment and Pollution Research, 2(3), 70-82.

Olaniyi, O. A., Olutimehin, I. O., \& Funmilayo, O. A. (2019). Review of climate change and its effect on Nigeria ecosystem. International journal of Rural Development, Environment and Health Research, 3(3), 92-100. https://dx.doi.org/10.22161/ijreh.3.3.3

Onoja, U. S., Dibua, U. M. E., \& Enete, A. A. (2011). Climate change: Causes, effects and mitigation measures-a review. Global Journal of Pure and Applied Sciences, 17(4), 469-479.

Oruonye, E. D. (2011). An assessment of the level of awareness of the effects of climate change among students of tertiary institutions in Jalingo Metropolis, Taraba State Nigeria. Journal of Geography and Regional Planning, 4(9), 513-517. https://doi.org/10.5897/JGRP.9000012

Pandve, H. T., Chawla, P. S., Fernandez, K., Singru, S. A., Khismatrao, D., \& Pawar, S. (2011). Assessment of awareness regarding climate change in an urban community. Indian Journal of Occupational and Environmental Medicine, 15(3), 109-112. https://doi.org/10.4103/0019-5278.93200

Parant, A., Pascual, A., \& Jugel, M. (2016). Raising students awareness to climate change: An illustration with binding communication. Environmental Behavior, 4(9), 339-353. https://doi.org/10.1177/0013916516629191

Pareek, N. (2017). Climate change impact on soils: Adaptation and mitigation. MOJ Ecology \& Environmental Sciences, 2(3), 136-139. https://doi.org/10.15406/mojes.2017.02.00026

Paternoster, R., \& Bachman, R. D. (2018). Essentials of statistics for criminology and criminal justice. California, USA: Sage Publications Inc. 
Plotnikoff, R. C., Wright, M., \& Karunamuni, N. (2004). Knowledge, attitudes and behaviors related to climate change in Alberta, Canada: Implications for public health policy and practice. International Journal of Environmental Research, 14(3), 223-229. https://doi.org/10.1080/0960312042000218633

Rahman, M. S., Overgaard, H. J., Pientong, C., Mayxay, M., Ekalaksananan, T., Aromseree, S. ... Haque, U. (2021). Knowledge, attitudes, and practices on climate change and dengue in Lao People's Democratic Republic and Thailand. Environmental Research, 193(110509), 1-11. https://doi.org/10.1016/j.envres.2020.110509

Ramesh, S. S. R., \& Negi, S. C. (2014). Improved agricultural practices to mitigate the effect of climate change. Himachal Journal of Agricultural Research, 40(1), 1-13.

Ramos, M. M. A., Ramos, P. L., Neto, F. L., \& Barba, P. C. (2019). Using software R in research in occupational therapy. Brazilian Journal of Occupational Therapy, 27(1), $217-230$. https://doi.org/10.4322/2526-8910.ctoCB1625

Rees, W. E. (2003). Impeding sustainability? The ecological footprint of higher education. Planning for Higher Education, 31(3), 88-98.

Sanneh, E. S., Hu, A. H., Hsu, C., \& Njie, M. (2013). Prioritization of climate change adaptation approaches in the Gambia. Mitigation and Adaptation Strategies for Global Change, 19(8), 1-16. https://doi.org/10.1007/s11027-013-9465-z

Schwirplies, C. (2018). Citizens' acceptance of climate change adaptation and mitigation: A survey in China, Germany, and the U.S. Ecological Economics, 145(C), 308-322. https://doi.org/10.1016/j.ecolecon.2017.11.003

Shrestha, B. M., Chang, S. X., Bork, E. W., Carlyle, C. N. (2018). Enrichment planting and soil amendments enhance carbon sequestration and reduce greenhouse gas emissions in agroforestry systems: A review. Forests, 9(6), 1-18. https://doi.org/10.3390/f9060369

Smith, P., \& Olesen, J. E. (2010). Synergies between the mitigation of, and adaptation to, climate change in agriculture. Journal of Agricultural Science, 148(5), 543-552. https://doi.org/10.1017/S0021859610000341

Sulistyawati, S., Mulasari, S.A., \& Sukesi, T.W. (2018). Assessment of knowledge regarding climate change and health among adolescents in Yogyakarta, Indonesia. Journal of Environmental and Public Health, 2018(9716831), 1-7. https://doi.org/10.1155/2018/9716831

Tobler C., Visschers, V. H. M., \& Siegrist, M. (2012). Consumers' knowledge about climate change. Climatic Change, 114, 189-209. https://doi.org/10.1007/s10584-011-0393-1

Turhan, N. S. (2020). Karl Pearson's chi-square tests. Educational Research and Reviews, 15(9), 575-580. https://doi.org/10.5897/ERR2019.3817

Yang, L., Liao, W., Liu, C., Zhang, N., Zhong, S., \& Huang, C. (2018). Associations between knowledge of the causes and perceived impacts of climate change: A cross-sectional survey of medical, public health and nursing students in universities in China. International Journal of Environmental Research and Public Health, 15(2650), 1-14. https://doi.org/10.3390/ijerph15122650

Yung, L., Phear, N., Dupont, A., \& Murphy, D. (2015). Drought adaptation and climate change beliefs among working ranchers in Montana. Weather, Climate, and Society, 7, 281-293. https://doi.org/10.1175/WCAS-D-14-00039.1

Zerrudo, O. D. L., Salain, N. A., \& Salain, H. A. (2017). Adaptation and mitigation of climate change: Awareness of Basilan State College freshman students. International Journal of Innovation and Research in Educational Sciences, 4(5), 547-552.

\section{Copyrights}

Copyright for this article is retained by the author(s), with first publication rights granted to the journal.

This is an open-access article distributed under the terms and conditions of the Creative Commons Attribution license (http://creativecommons.org/licenses/by/4.0/). 